\title{
IMPLEMENTATION OF MIND MAPPING METHOD COMBINED WITH MAKE A MATCH TECHNIQUES ON COOPERATION ATTITUDE AND STUDENT LEARNING OUTCOMES
}

\author{
Rizki Rahmadhani*, Zulkifli Simatupang \\ Program Studi Pendidikan Biologi, FMIPA, Universitas Negeri Medan, Medan \\ Jl. Willem Iskandar Psr. V Medan Estate, Medan, Indonesia, 20221 \\ *Korespondensi Author: rizkirahmadhani12@gmail.com
}

\section{INFO ARTIKEL}

Histori Artikel

Received 11 Juli 2018

Revised 26 Maret 2020

Accepted 27 Maret 2020

Published 2 April 2020

Keywords:

Make A Match Technique, Mind Mapping Method, Student

Cooperation

\begin{abstract}
This study aims to describe the implementation of Biology learning using the Mind Mapping method combined with the Make A Match technique. The study used a descriptive research design. The whole series of research processes are conducted with the standards of graduates, processes standard, and assessment standards applied in the 2013 curriculum. The implementation phase of instruction is done: 1) Measurement of teacher's ability to prepare a lesson plan and implement teaching-learning; 2) The attitude of students cooperation when composing a Mind Mapping on the material of the human excretion system; 3 ) Measurement of student learning outcomes. Data analysis was done by the descriptive statistic technique, in mean form, standard deviation, frequency distribution, and description of learning recordings. As a result, the teacher can implement well the Biology learning device material of the human excretion system in class XI MIA Lubuk Pakam MAN using the Mind Mapping method combined with the Make A Match technique. The collaboration of students in class XI MIA MAN Lubuk Pakam when composing a Mind Mapping is in a good category. The distribution of mastery learning in class XI MIA MAN Lubuk Pakam after learning the Mind Mapping method combined with Make A Match technique is $76,1 \%$ of students reaching completeness and $23,9 \%$ unfinished. The learning mastery in the Mind Mapping method combined with the Make A Match technique is higher than the previous daily test.
\end{abstract}

Copyright $(2019$ Universitas Negeri Medan. Artikel Open Access dibawah lisensi CCBY-4.0 (https://creativecommons.org/licenses/by/4.0)

How To Cite:

Rahmadhani, R., \& Simatupang, Z. (2020). Implementation of Mind Mapping Method Combined with Make A Match Techniques on Cooperation Attitude and Student Learning Outcomes. Jurnal Pelita Pendidikan, 8(1), 012-019.

\section{PENDAHULUAN}

Pendidikan merupakan proses interaksi yang terjadi antara guru dan siswa yang memiliki tujuan meningkatkan pengembangan mental sehingga siswa menjadi mandiri dan aktif. Belajar hakikatnya adalah suatu proses yang ditandai dengan adanya perubahan pada diri seseorang. Perubahan sebagai hasil dari proses belajar dapat diindikasikan dalam berbagai bentuk seperti pengetahuan, pemahaman, sikap, tingkah laku, kecakapan, keterampilan dan kemampuan. Perubahan ini harus pula diikuti oleh guru yang bertanggung jawab atas penyelenggaraan pembelajaran disekolah. Satu inovasi yang menarik mengiringi perubahan tersebut adalah diterapkannya model pembelajaran inovatif, progresif dan kontekstual yang dengan tepat dapat mengembangkan dan 
menggali pengetahuan peserta didik (Trianto, 2014).

Pembelajaran kurikulum 2013 lebih mengedepankan peran siswa dalam proses pembelajaran. Guru bertugas sebagai fasilitator, sehingga dalam aplikasinya, pembelajaran yang berpusat kepada siswa dapat menumbuhkan interaksi antara guru dan siswa ataupun sebaliknya. Konsep tersebut sejalan dengan pendidikan interaksional. Pendidikan interaksional lebih menekankan interaksi dua pihak, dari guru kepada siswa dan dari siswa kepada guru. Interaksi yang terjadi antara siswa dan siswa ataupun siswa dan lingkungan dapat diciptakan melalui proses kerja sama. Namun pada umumnya siswa kurang berpartisipasi, artinya kurang aktif dalam proses pembelajaran. Siswa bersikap pasif, hanya mendengarkan penjelasan guru, kemudian mencatat apa yang ditulis ataupun yang diucapkan oleh guru.

Berdasarkan hasil observasi di MAN Lubuk Pakam diketahui fakta-fakta berikut: (1) Sekolah MAN Lubuk pakam sudah menjalankan kurikulum 2013; (2) KKM mata pelajaran Biologi adalah 78; (3) Dalam pelaksanaan pembelajaran di kelas guru biologi tidak hanya menerapkan metode ceramah saja, metode diskusi juga sudah dilakukan, tetapi dalam proses pembelajaran menggunakan metode diskusi kelompok tersebut masih terlihat bahwa siswa cenderung hanya ingin memperlihatkan kemampuannya sendiri bukan kelompoknya; (4) Seringkali hasil dari kelompok tersebut memang bagus tetapi bukan hasil dari kerja sama setiap anggota kelompok, melainkan hasil dari beberapa anggota yang memang mempunyai intelektual yang lebih dari anggota yang lain; (5) Siswa yang tidak aktif di dalam kelompok melakukan kegiatan lain seperti mengganggu teman yang lain, pergi ke kelompok lain, dan tidur-tiduran; (6) Dalam kegiatan belajar sering dijumpai siswa selalu mencatat dalam bentuk catatan secara linier. Catatan dalam bentuk linier panjang yang mencakup seluruh isi pelajaran terlihat monoton dan membosankan; (7) Siswa kesulitan dalam membaca dan mengulang pembelajaran yang telah dipelajari. Hal tersebut berpengaruh terhadap hasil belajar siswa, hanya 43,7\% siswa yang mencapai Kriteria Ketuntasan Minimal (KKM 78) dan selebihnya harus melakukan remedial.
Mengingat pentingnya mata pelajaran Biologi untuk siswa yang mengambil program IPA, maka berbagai hal dapat dilakukan oleh guru untuk menyusun suatu pembelajaran yang menarik dan dapat meningkatkan pemahaman setiap peserta didik. Misalnya pada sub materi sistem ekskresi manusia yang merupakan materi biologi yang bersifat anatomis dan fisiologis. Umumnya siswa tertarik pada sub materi yang berkaitan dengan permasalahan yang ditemui dalam keseharian, namun siswa mengalami kesulitan dalam memahami sub materi yang bersifat fisiologis.

Menurut Sari (2013) dari segi siswa penyebab sulitnya siswa memahami materi biologi dalam pelajaran adalah siswa menganggap materi biologi bersifat hafalan. Oleh karena itu, untuk mengubah cara berfikir siswa yang sulit memahami pelajaran biologi perlu upaya untuk mengubah proses pembelajaran dengan menggunakan model pembelajaran yang melibatkan keaktifan siswa sehingga diharapkan dapat meningkatkan keberhasilan dalam prestasi belajar siswa.

Dari uraian permasalahan di muka diketahui bahwa perlu adanya perbaikan dalam proses pembelajaran yang dapat meningkatkan keterlibatan siswa selama proses pembelajaran. Berdasarkan hasil penelitian Utami dan Hasanah (2016) model pembelajaran kooperatif sangat cocok diterapkan pada pembelajaran biologi, karena dalam mempelajari biologi tidak cukup hanya mengetahui dan menghapal konsep-konsep tetapi juga dibutuhkan suatu pemahaman serta kemampuan menyelesaikan persoalan biologi dengan baik dan benar. Melalui pembelajaran model kooperatif siswa dapat mengemukakan pikirannya, saling bertukar pendapat, saling bekerja sama jika ada teman yang mengalami kesulitan. Banyak model pembelajaran kooperatif yang dapat digunakan guru seperti NHT, TGT, STAD, Group investigation, Mind Mapping, Jigsaw, dan Make a Match.

Pada laporan penelitian ini, telah dilakukan pembelajaran Biologi di MAN Lubuk Pakam menggunakan metode Mind Mapping dikombinasi dengan Teknik Make a Match terkait dengan materi Sistem Ekskresi Manusia. Mind map merupakan salah satu teknik mencatat yang dikemukakan oleh Tony Buzan. Catatan yang dibuat tersebut membentuk gagasan yang saling berkaitan, dengan 
topik utama di tengah dan subtopik serta perincian menjadi cabang-cabangnya. Hal tersebut dapat menjadikan siswa merasa senang dan tidak bosan dalam mengikuti pelajaran, sehingga dapat meningkatkan hasil belajar. Dengan mind map, daftar infomasi yang panjang dapat menjadi diagram warna-warni, teratur, dan mudah diingat yang bekerja selaras dengan kerja alami otak dalam melakukan berbagai hal (Fauziah, 2016). Menurut Tika dalam Darmayoga, dkk, (2013) Mind Mapping adalah cara mencatat yang kreatif, efektif, dan memetakan pikiran-pikiran kita, secara menarik, mudah dan berdayaguna. Selanjutnya, berdasarkan penelitian yang dilakukan Darmayoga, dkk, (2013) didapat bahwa hasil belajar siswa yang mengikuti metode pembelajaran Mind Mapping memiliki skor rata-rata sebesar 73,05 lebih tinggi dari pada hasil belajar siswa yang mengikuti metode pembelajaran konvensional yang memiliki skor rata-rata sebesar 60,63 .

Sedangkan teknik pembelajaran Make a Match atau mencari pasangan dikembangkan oleh Lorna Curran pada tahun 1994, model ini menggunakan kartu-kartu. Kartu-kartu tersebut terdiri dari kartu yang berisi pertanyaanpertanyaan dan kartu-kartu lainnya berisi jawaban dari pertanyaan tersebut. Dalam Ramadhan dan Santosa (2018), Anita lie menyatakan bahwa pembelajaran tipe Make a Match atau bertukar pasangan merupakan teknik belajar yang memberi kesempatan siswa untuk bekerja sama dengan orang lain. Teknik ini bisa digunakan dalam semua mata pelajaran dan untuk semua tingkatan anak usia didik. Dengan menggunakan model pembelajaran tipe make a match, siswa belajar sambil bermain untuk memberikan peluang siswa belajar secara santai dengan menumbuhkan rasa tanggung jawab, kerjasama yang baik, persaingan yang sportif dan keterlibatan belajar (Iwan dan Lestari, 2015). Penelitian Iryani (2013) menunjukkan bahwa penerapan model pembelajaran Make a Match dapat meningkatkan aktivitas dan hasil belajar biologi siswa dengan ratarata daya serap siswa siklus I yaitu $66,81 \%$ (kurang) dan meningkat pada siklus II dengan rata-rata $82,16 \%$ (cukup).

Berdasarkan uraian diatas diketahui bahwa metode Mind Mapping maupun teknik Make a Match dapat meningkatkan hasil belajar siswa dan dapat membangun sikap kerja sama siswa selama proses belajar mengajar berlangsung.

\section{METODE PENELITIAN}

Penelitian ini telah dilakukan di kelas XI MAN Lubuk Pakam Jl. Karya Agung Komplek Pemkab Deli Serdang. Penelitian berlangsung selama 3 (tiga) bulan, sejak bulan Maret sampai bulan Mei 2018. Populasi dalam penelitian ini adalah siswa kelas XI MAN Lubuk Pakam semester genap T.P 2017/2018 berjumlah 71 orang dibagi ke dalam 2 kelas paralel. Pengambilan sampel dalam penelitian ini menggunakan teknik purposive sampling.

Jenis penelitian ini merupakan penelitian deskriptif. Penelitian deskriptif menggambarkan keadaan tertentu semaksimal mungkin sesuai dengan keadaan sebenarnya. Deskripsi dilakukan terhadap: 1) Kemampuan guru dalam mengimplementasikan perangkat pembelajaran; 2) Sikap kerja sama siswa ketika menyusun Mind Mapping pada materi sistem ekskresi manusia; 3) Hasil belajar siswa kelas XI setelah mendapatkan pembelajaran metode Mind Mapping dikombinasi dengan teknik Make A Match.

Tahap persiapan penelitian meliputi: mengurus surat observasi ke sekolah sasaran, melakukan observasi ke sekolah MAN Lubuk Pakam, meminta izin kepada pihak sekolah untuk melakukan penelitian di sekolah tersebut, wawancara dengan guru Biologi, menentukan kelas yang menjadi sampel penelitian, menyusun rencana pelaksanaan pembelajaran (RPP) mengikuti kebutuhan penyusunan komponen RPP yang dianjurkan pada Standar Proses Kurikulum 2013 sebagaimana dituangkan dalam Permendikbud Nomor 22 Tahun 2016, membuat instrument penelitian, dan menyusun proposal penelitian yang berisikan masalah yang akan diteliti.

Tahap pelaksanaan penelitan terdiri atas beberapa tahapan, yakni: melakukan pretest di kelas XI MIA-2 dan XI MIA-3 MAN Lubuk Pakam sebelum dilakukannya pembelajaran, melaksanakan proses pembelajaran sistem ekskresi manusia menggunakan metode Mind Mapping dikombinasi dengan teknik Make A Match di dua kelas secara paralel, mengamati kerja sama siswa dan melakukan posttest setelah pembelajaran 
sistem ekskresi manusia menggunakan metode Mind Mapping dikombinasi dengan teknik Make A Match selesai. Selama proses pelaksanaan pembelajaran sistem ekskresi manusia di kelas XI MAN Lubuk Pakam menggunakan metode Mind Mapping dikombinasi dengan teknik Make a Match dilakukan pengumpulan data-data penelitian berupa penilaian RPP, kemampuan menerapkan perangkat pembelajaran, data kuantitatif yang terdiri dari Pretest dan posttest, pengumpulan data kualitatif yang terdiri dari rekaman pembelajaran, Mind Mapping siSwa dan sikap kerja sama siswa. Hasil rekaman pembelajaran selanjutnya dilaporkan dalam bentuk deskripsi berupa vignette.

Sebelum penelitian ini dilaksanakan, terlebih dahulu peneliti melakukan validasi instrumen. Validasi dilakukan dengan validasi internal yang ditempuh melalui uji konstrak (construct validity) dan uji isi (content validity). Pengujian dilakukan dengan review dari seorang ahli uji konstrak dan seorang ahli isi. Ahli konstrak ditentukan berdasarkan kualifikasi akademik di bidang kependidikan/pendidikan biologi, dan ahli isi ditentukan berdasarkan kualifikasi akademik di bidang ilmu biologi khususnya fisiologi. Analisis data dilakukan dengan teknik statistik deskriptif, dalam bentuk rata-rata, simpangan baku, distribusi frekuensi, dan deskripsi rekaman pembelajaran yang disusun dalam bentuk vignette.

\section{HASIL DAN PEMBAHASAN}

\section{Kemampuan Guru Menerapkan Metode Mind Mapping Dikombinasi Teknik Make A Match}

Penilaian kemampuan guru dalam menerapkan pembelajaran dilakukan dengan menggunakan lembar pengamatan. Hasil penilaian tersebut diperoleh rata-rata kemampuan guru sebesar $3,78 \pm 0,41$, dengan sebaran nilai menurut aspek penilaian sebagaimana ditunjukkan pada Gambar 1.

Berdasarkan Gambar 1, ditemukan bahwa kesesuaian pembelajaran dengan RPP dalam mengimplementasikan pembelajaran Mind Mapping Dikombinasi dengan Teknik Make A Match di MAN Lubuk Pakam menunjukkan kualitas baik $(N=90,4)$ dengan rincian sebagai berikut: aspek yang memperoleh skala 4 yakni pada aspek penilaian: 3) Pemanfaatan sumber belajar/media pembelajaran Mind Mapping dikombinasi dengan Teknik Make A Match; dan aspek 5) Penilaian proses dan hasil belajar Mind Mapping Dikombinasi dengan Teknik Make A Match. Sedangkan pada aspek penilaian lainnya memperoleh nilai <4, yakni aspek: 1) Pra Pembelajaran Mind Mapping Dikombinasi dengan Teknik Make A Match; 2) Kegiatan inti pembelajaran Mind Mapping Dikombinasi dengan Teknik Make A Match; 7) Aspek penutup; 6) Penggunaan bahasa; dan 4) Pembelajaran Mind Mapping Dikombinasi dengan Teknik Make A Match yang memicu keterlibatan siswa.

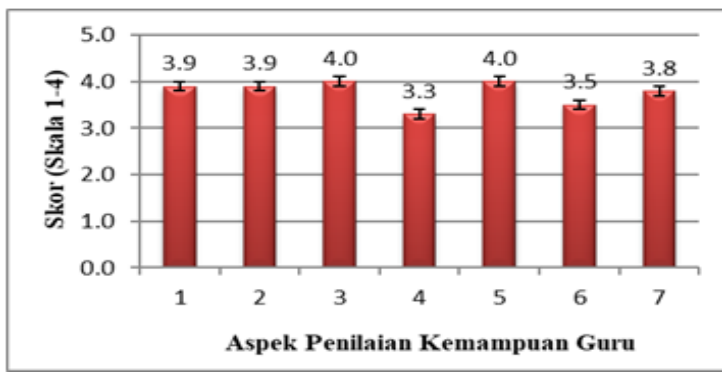

Keterangan:

1. Pra Pembelajaran

2. Kegiatan inti

3. Pemanfaatan sumber belajar/media

4. Pembelajaran yang memicu keterlibatan siswa

5. Penilaian proses dan hasil belajar

6. Penggunaan bahasa

7. Penutup

Gambar 1. Kemampuan Guru Menerapkan Metode Mind Mapping Dikombinasi Teknik Make A Match

Penerapan model pembelajaran sangat ditentukan oleh kesiapan guru merancang dan mengimplementasikan model pembelajaran selama proses belajar mengajar berlangsung. Kesiapan guru merancang suatu pembelajaran dilihat dari penilaian RPP yang dibuat oleh peneliti dan dinilai oleh guru mitra. Secara umum, ciri-ciri RPP yang baik adalah sebagai berikut: (1) memuat aktivitas proses belajar mengajar yang akan dilaksanakan oleh guru, yang akan menjadi pengalaman belajar bagi siswa; (2) langkah-langkah pembelajaran disusun secara sistematis agar tujuan pembelajaran dapat dicapai; (3) langkah-langkah pembelajaran disusun serinci mungkin, sehingga apabila RPP digunakan oleh guru lain mudah dipahami dan tidak menimbulkan penafsiran ganda (Chusni, 2017). 


\section{Sikap Kerja Sama Siswa Ketika Menyusun Mind Mapping}

Sikap kerja sama yang diamati memiliki 7 indikator. Dari hasil pengamatan, diperoleh data tabulasi nilai rata-rata indikator sikap kerja sama siswa menggunakan metode Mind Mapping dikombinasi dengan Teknik Make A Match diperoleh nilai rata-rata $89,5 \pm 5,7$, dengan sebaran nilai pada tiap indikator penialian seperti Gambar 2.

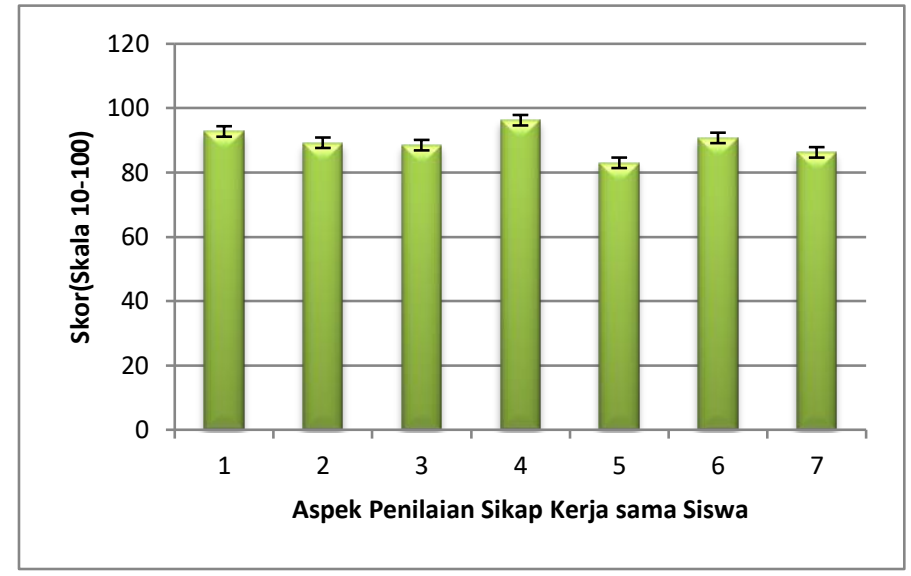

Keterangan :

1. Menggunakan kesepakatan

2. Menghargai kontribusi setiap anggota kelompok

3. Mengambil giliran dan berbagi tugas

4. Berada dalam kelompok selama kegiatan berlangsung

5. Mendorong anggota kelompok untuk berpartisipasi terhadap tugas

6. Mengungkapkan ketidaksetujuan dengan cara santun

7. Menyimpulkan hasil pemecahan masalah dalam kelompok

Gambar 2. Sikap kerja sama siswa ketika menyusun Mind Mapping pada materi sistem ekskresi manusia

Berdasarkan Gambar 2, diketahui bahwa nilai rata-rata indikator kerja sama siswa ketika menyusun Mind Mapping dari yang tertinggi hingga yang terendah adalah (4) berada dalam kelompok selama kegiatan berlangsung, (1) Menggunakan kesepakatan, (6) mengungkapkan ketidaksetujuan dengan cara santun, (2) menghargai kontribusi setiap anggota kelompok, (3) mengambil giliran dan berbagi tugas, (7) menyimpulkan hasil pemecahan masalah dalam kelompok, dan (5) mendorong anggota kelompok untuk berpartisipasi terhadap tugas.

Sikap kerja sama siswa menyusun Mind Mapping pada materi sistem ekskresi manusia dikategorikan baik menunjukkan terlaksananya suatu tujuan pembelajaran yaitu dapat membangun sikap kerja sama siswa dalam kelompok. Tujuan dari bekerja sama ialah dapat mengembangkan tingkat pemikiran yang tinggi, keterampilan komunikasi yang penting, meningkatkan minat, percaya diri, kesadaran bersosial dan sikap toleransi terhadap perbedaan individu. Dalam kerjasama, kita memiliki kesempatan mengungkapkan gagasan, mendengarkan pendapat orang lain, serta bersama-sama membangun pengertian, menjadi sangat penting dalam belajar karena memiliki unsur yang berguna menantang pemikiran dan meningkatkan harga diri seseorang. Kerja sama merupakan salah satu nilai yang perlu ditanamkan kepada siswa, salah satunya dengan model pembelajaran kooperatif (Rahmawati, 2014).

\section{Hasil Belajar Kognitif}

Penilaian hasil belajar dirancang berdasarkan tujuan pembelajaran untuk mengukur ranah kognitif, afektif, dan psikomotorik, juga mengukur kemampuan berpikir kritis dan kreatif, keterampilan berpikir dan kemandirian dalam pemecahan masalah.Perancangan penilaian hasil 
belajar sebaiknya tidak hanya mengukur kemampuan hafalan, pemahaman saja, namun lebih dapat mengukur dan menciptakan (Hasruddin dkk, 2018).

Hasil belajar siswa setelah mengikuti pembelajaran Biologi menggunakan metode Mind Mapping dikombinasi dengan teknik Make A Match di peroleh nilai terendah 60 dan tertinggi 90 (rentang=30). Nilai rata-rata ini lebih tinggi dibanding hasil pretest $(53,3 \pm 18,2)$ dengan ratarata nilai siswa sebesar $(80,8 \pm 6,6)$ dan nilai $\mathrm{N}$-gain diperoleh sebesar 57,1 dengan kategori sedang. Perbandingan nilai rata-rata tersebut ditunjukkan pada Gambar 3.

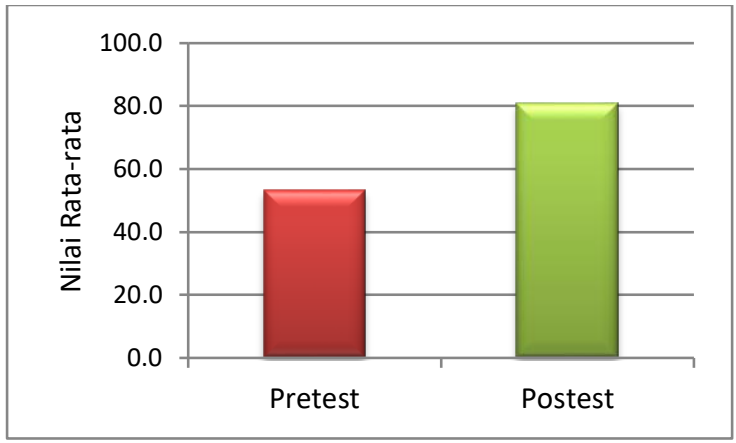

Gambar 3. Perbandingan Rata-rata Hasil Belajar Siswa $(N$-gain $=57,1)$

Gambar 4 menunjukkan bahwa terjadi pergeseran sebaran siswa terbanyak dari rentang nilai 31-40 dan 41-50 pada hasil pretest (sebelum pembelajaran Metode Mind Mapping dikombinasi dengan teknik Make A Match) ke rentang 71-80 $(33,8 \%)$ dan $81-90(56,8 \%)$ setelah pembelajaran Metode Mind Mapping dikombinasi dengan teknik Make A Match diterapkan pada pembelajaran Biologi di kelas XI MIA MAN Lubuk Pakam T.P 2017/2018.

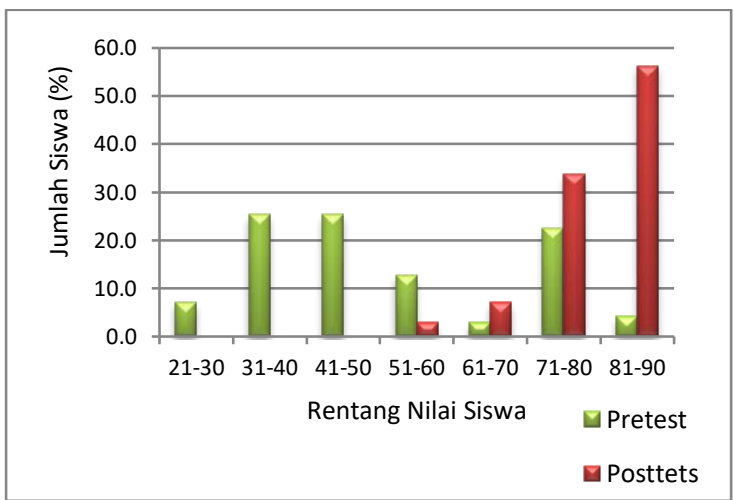

Gambar 4. Distribusi Nilai Hasil Belajar Siswa
Dari persentase siswa yang mencapai ketuntasan belajar, juga menunjukkan bahwa persentase siswa yang mencapai ketuntasan belajar (nilai $\geq 78$ ) pada postest setelah siswa mengikuti kegiatan belajar mengajar Biologi menggunakan metode Mind Mapping dikombinasi dengan teknik Make A Match lebih tinggi $(76,1 \%)$ dibandingkan dengan hasil pretest (sebelum mendapat pembelajaran metode Mind Mapping dikombinasi dengan teknik Make A Match) (26,8\%). Hasil ini memberi makna, bahwa pembelajaran Biologi menggunakan metode Mind Mapping dikombinasi dengan teknik Make A Match di kelas XI MIA MAN Lubuk Pakam T.P 2017/2018 memberikan kontribusi bagi peningkatan hasil belajar siswa (Gambar 5).

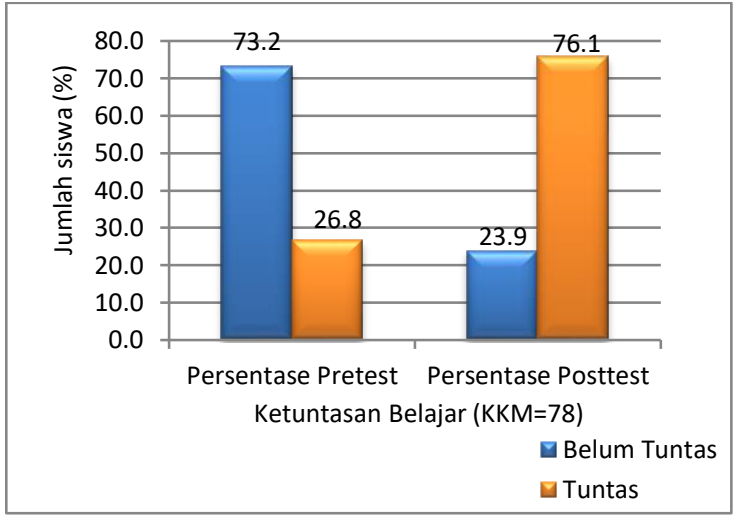

Gambar 5. Perbandingan Ketuntasan Belajar Siswa

Berdasarkan hasil penelitian, diketahui bahwa perolehan selisih antara nilai posttetst dan nilai pretest tergolong sedang ditunjukkan dengan perolehan nilai $\mathrm{N}$-gain sebasar 57,1. Hal ini mengindikasikan bahwa peningkatan pemahaman siswa dalam pembelajaran Biologi materi sistem ekskresi manusia tergolong sedang. Selanjutnya diketahui bahwa jumlah siswa yang mencapai nilai KKM (78) setelah mendapat pembelajaran Biologi menggunakan Metode Mind Mapping dikombinasi Dengan Teknik Make A Match lebih tinggi $(76,1 \%)$ dibanding dengan hasil pretest (26,8\%). Hal ini menunjukkan bahwa penerapan Metode Mind Mapping dikombinasi Dengan Teknik Make A Match pada pembelajaran Biologi siswa kelas XI MIA MAN Lubuk Pakam dapat meningkatkan hasil belajar siswa. Peningkatan hasil belajar siswa tersebut disebabkan karena sebelum penelitian ini dilakukan siswa sudah mempelajari materi sistem ekskresi 
manusia. Selain itu, penerapan metode Mind Mapping dikombinasi dengan teknik Make A Match memberikan suatu pengalaman belajar kepada siswa dan cara mencatat dengan metode Mind Mapping membuat siswa mudah dalam membaca dan memahaminya sehingga dapat memudahkan siswa dalam pemahaman.

\section{Kemampuan Siswa Membuat Mind Mapping Pada Materi Sistem Ekskresi Manusia}

Hasil penilaian Mind Mapping yang dibuat siswa selama proses belajar mengajar Biologi materi sistem ekskresi manusia di kelas XI MIA MAN Lubuk Pakam diperoleh nilai rata-rata sebesar $2,4 \pm 0,7$, dengan sebaran nilai pada tiap indikator penilaian sebagaimana ditunjukkan pada Gambar 6 berikut ini.

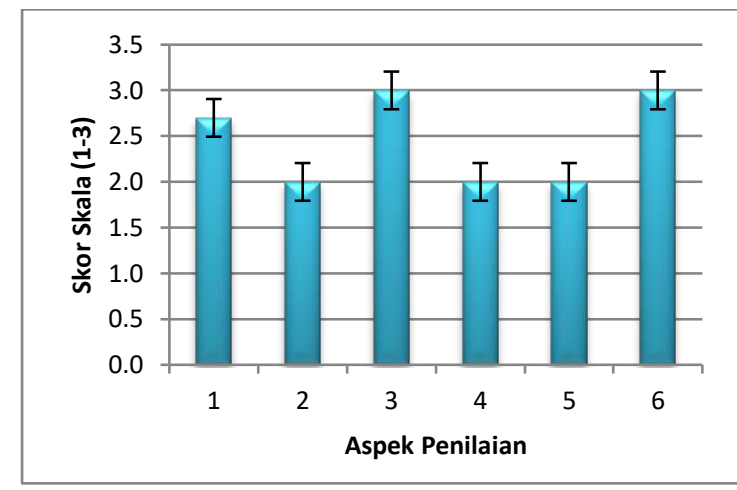

Keterangan:

1. Penempatan ide sentral

2. Penggunaan gambar/foto untuk ide sentral

3. Penggunaan warna

4. Penggunaan garis melengkung

5. Kata kunci

6. Penulisan Kata Kunci

Gambar 6. Kemampuan Mind Mapping Siswa

Berdasarkan Gambar 6, Mind Mapping siswa tergolong baik $(\mathrm{N}=83)$ dengan perolehan rata-rata sebesar 2,4 40,7 . Aspek tertinggi yaitu pada penilaian penggunaan warna dengan rata-rata nilai sebesar 3,0. Hal tersebut dikarenakan siswa menggunakan warna lebih dari 3 warna. Siswa menyadari penggunaan warna akanmembuat Mind Map menjadi menarik dan sangat membantu siswa dalam mengingat suatu konsep. Selain itu aspek penulisan kata kunci juga memperoleh penilaian tertinggi dengan rata-rata nilai sebesar 3,0. Penulisan kata kunci akan membantu siswa dalam menemukan suatu konsep. Jika kata kunci di tulis dengan huruf kapital semua, maka siswa lebih mudah menemukan konsep yang dicari.Kemudian aspek yang memperoleh nilai dibawah 3 yaitu aspek penempatan ide sentral dengan rata-rata sebesar 2,7. Penempatan ide sentral merupakan ciri utama dari sebuah Mind Mapping. Ide sentral di tempatkan ditengah kertas. Penyimpanan ide sentral ini sesuai dengan kerja otak yang merupakan prinsip dasar pembuatan Mind Mapping. Berdasarkan hasil Mind Mapping yang di buat siswa, rata-rata siswa meletakkan ide sentral di bagian tengah kertas. Kemudian penggunaan gambar/foto untuk ide sentral dengan rata-rata sebesar 2,0. Dalam membuat Mind Mapping, ada beberapa kelompok yang sudah menggunakan foto/gambar sendiri untuk ide sentral.Selain membuat Mind Mapping menraik, hal tersebut juga dapat menunjukkan dengan jelas ide sentral.Namun ada beberapa kelompok yang tidak menggunakan gambar untuk ide sentral. Hal tersebut dikarenakan waktu dalam menyusun Mind Mapping hanya 15 menit dan kurangnya kerja sama siswa dalam menyelesaikan Mind Mapping. Selanjutnya aspek penggunaan garis melengkung dengan rata-rata sebesar 2,0. Siswa masih kesulitan dalam memahami penggunaan garis lengkung. Selain membuat menarik, penggunaan garis lengkung juga berfungsi untuk menghubungkan suatu konsep. Dan yang terakhir yaitu aspek kata kunci dengan rata-rata sebesar 2,0. Penggunaan Mind Mapping ini merupakan hal baru bagi sebagian besar siswa sehingga siswa mengalami kesulitan dalam mengimajinasikan kata-kata atau kalimat panjang menjadi sebuah kata kunci.

\section{KESIMPULAN}

Berdasarkan hasil penelitian dan pembahasan yang telah diuraikan dapat disusun simpulan penelitian yaitu secara umum guru dapat mengimplementasikan dengan baik perangkat pembelajaran Biologi materi ajar sistem ekskresi manusia di kelas XI MIA MAN Lubuk Pakam menggunakan metode Mind Mapping dikombinasi dengan teknik Make A Match dan kerja sama siswa kelas XI MAN Lubuk Pakam ketika menyusun Mind Mapping tergolong baik. Aspek paling rendah ditemukan pada aspek mendorong anggota kelompok untuk berpartisipasi terhadap tugas serta 
hasil belajar siswa ditinjau dari tes kognitif menunjukkan bahwa siswa kelas XI MAN Lubuk Pakam setelah mendapatkan pembelajaran metode Mind Mapping dikombinasi dengan teknik Make A Match adalah $76,1 \%$ siswa yang mencapai ketuntasan belajar dan 23,9\% siswa belum tuntas. Ketuntasan belajar pada metode Mind Mapping dikombinasi dengan teknik Make A Match lebih tinggi dibanding sebelum menerapkan metode Mind Mapping dikombinasi dengan teknik Make A Match. Dan kemampuan siswa dalam membuat Mind Mapping pada materi sistem ekskresi manusia tergolong baik ( $\mathrm{N}=83$ ).

\section{DAFTAR PUSTAKA}

Buzan, T. (2006). Buku Pintar Mind Map. Gramedia Pustaka Utama, Jakarta.

Chusni, M. M., Setya, W., Agustina, R. D., \& Malik, A. (2017). Peningkatan kemampuan menyusun rencana pelaksanaan pembelajaran (RPP) berbasis saintifik bagi calon guru fisika. Scientiae Educatia: Jurnal Pendidikan Sains, 6(2), 125-143.

Iryani, S. Penerapan Model Pembelajaran Kooperatif Make A Match Untuk Meningkatkan Aktivitas Dan Hasil Belajar Biologi Siswa Kelas X. 2 SMA Negeri 10 Pekanbaru Tahun Ajaran 2012/2013. Biogenesis (Jurnal Pendidikan Sains Dan Biologi), 9(2), 1-13.

Darmayoga, I, W., I Wayan, L., dan Marhaeni, A. (2013). Pengaruh Implementasi Metode Mind Mapping Terhadap Hasil Belajar IPS Ditinjau Dari Minat Siswa Kelas IV SD Sathya Dendapsar, e-Journal Program Pascasarjana Universitas Pendidikan Ganesha Jurusan Pendidikan Dasar, 3(1), 1-11.

Fauziah, R., \& Alatas, F. (2016). Pengaruh Lembar Kerja Siswa Berbasis Mind Map Terhadap Hasil Belajar Siswa SMA Pada Konsep Fluida Statis. EDUSAINS, 8(1), 1-8.

Hamalik, O. (2010) Proses Belajar Mengajar. Bumi Aksara, Jakarta.

Hasruddin, H., Harahap, F., \& Mahmud, M. (2018, June). Penyusunan Instrumen Tes Kemampuan Berpikir Tingkat Tinggi Pada Perkuliahan Mikrobiologi Berbasis Kontekstual Di Pendidikan Biologi Unimed. In Prosiding Seminar Nasional Pendidikan Biologi (Vol. 1, No. 1, pp. 69-75).

Iwan, I., \& Lestari, N. P. P. (2015). Penerapan
Model Pembelajaran Kooperatif Tipe Make A Match Untuk Meningkatkan Motivasi Dan Hasil Belajar Biologi Pada Materi Ekosistem. Jurnal Nalar Pendidikan, 3(2).

Ramadhan, M. I., dan Santosa, A, B. (2018). Pengembangan Perangkat Pembelajaran Kooperatif Tipe Make a Match Pada Mata Pelajaran Perekayasaan Sistem Radio Dan Televisi Kelas XI Di SMKN 3 Surakarta. Jurnal Pendidikan Teknik Elektro, 7(1), 65-70.

Sari, L. Y. (2013). Analisis proses Pembelajaran Biologi Pada Materi Protista di Kelas X SMA Negeri 1 Batang Anai Kabupaten Padang Pariaman. Prosiding Semirata, FMIPA, Unila, 53-58.

Trianto (2014). Mendesain Model Pembelajaran Inovatif, Progresif dan Konsteksual. Prenada Media Kencana, Jakarta. 